\author{
Zhylenko, T.I. ${ }^{1}$, Kudryavtsev, A.M. ${ }^{1}$, and Zakharkevich, O.V. ${ }^{2}$ \\ ${ }^{1}$ Department of Mathematical Analysis and Optimization Methods, Sumy State University, \\ 2, Rymskiy-Korsakov St., Sumy, 40007, Ukraine, \\ +380661886616, t.zhylenko@phe.sumdu.edu.ua \\ ${ }^{2}$ Department of Clothing Design and Technology, Khmelniytskyi National University, \\ 11, Institutska St., Khmelnytskyi, 29016, Ukraine, \\ +380 67749 1647, zbir_vukladach@ukr.net
}

\title{
MOBILE APPLICATION TO CALCULATE THE PARAMETERS OF TOP WEAR BASIC DESIGN
}

\begin{abstract}
Introduction. Thanks to a rapid advancement of technology, the clothing industry is rapidly developing into a high-tech and capital-intensive production. This contributes to a high quality of design, pattern cutting, and manufacture. The industry is one of the fastest growing in the manufacture sector. Therefore, it is extremely important to enable industry professionals and researchers to keep pace with changes to achieve the desired competitiveness of products. Mobile applications for the garment industry (Stylebook, Cloth, Polyvore, etc.) have been analyzed. These applications contain galleries of clothing models, but only for specific styles of fashion and unrecognizable sizes. Therefore, they can be used as a guide for creating clothes of similar fashion styles but without the necessary level of accuracy.

Problem Statement. Mobile applications that are now available for use in the clothing industry are oriented towards the sale of finished products. Since the design and manufacturing stages are provided with software products only at the "home" level, there is a need for the development of mobile applications for clothing industry experts. To develop such an application, it is advisable to choose a design methodology that is both simple, accessible, and known to a wide range of users.

Purpose. To develop a mobile application for calculating the parameters of the main blocks of clothing.

Materials and Methods. To create our application, an advanced and convenient programming language Kotlin has been used.

Results. Based on the comparative analysis of the means of calculating the basic clothing designs, the expediency of using mobile applications in the garment industry has been proved. The existing mobile applications that are used or can be used in the design and manufacture of clothing have been classified. The quantitative classification analysis has confirmed the original hypothesis on the lack of mobile applications used while making a typical basic design. To calculate the parameters of the basic design of top wear, a mobile application has been developed. It provides support for the automated process of creating clothes designs, both in individual or small-scale production, as well as in the learning process.

Conclusions. The developed package enables making specific drawings for top wear of any size. The user gets the coordinates of basic design for making patterns for mass production or for individual pattern cutting.
\end{abstract}

Keywords: mobile application, Kotlin, class, package, and interface.

From labor-intensive, mechanically simplistic roots, the clothing industry is quickly becoming a high-tech, capital-intensive industry due to rapid advances in technology which contribute to high quality design, cutting, stitching, and finishing techniques. The industry is one of the fastest de-

(C) ZHYLENKO, T.I., KUDRYAVTSEV, A.M., and ZAKHARKEVICH, O.V., 2019 veloping in the manufacturing sector, and it is essential that industry practitioners and researchers keep pace with the changes if they are to develop streamlined manufacturing processes and keep ahead of their competitors. For that reason, even designers who work at the small enterprises are obliged to use computer-aided design whenever it is possible to accomplish. However, tailor 
shops usually do not use any CAD systems, while the requirements to the accuracy and speed are strict because their work is bespoke tailoring. Thus, the main objective of the study is to develop a means, which would be available to the average consumer, to support weakly automated clothing design process in tailor shops and other small clothing design enterprises.

Pattern cutting from blocks or adaptation of existing patterns is now widely used by the dress trade because of its accuracy of sizing and the speed with which ranges can be developed [1-5]. It is possible to calculate the basic patterns parameters by using one of the follows means: a specific mobile application, a pattern design system (PDS), a spreadsheet program like Microsoft Excel or other like the mentioned one, and an electronic calculator. The mentioned means must be compared by the main criteria, which are crucial for any patternmaker, who is working at the small enterprise or is self-employed. These criteria are as follows: speed, precision, cost and convenience of usage (Table).

Pattern design systems are very useful means to speed up designer's work. However, PDS is far too costly tool to be used by every clothing designer. PDS usually requires some specific peripheral devices such as a plotter or a digitizer. Furthermore, in order to use PDS it is mandatory to know how it works. However, it is only for last fifteen years the courses, which are devoted to study of the PDS, are in the curriculum at the universities. There were no such courses before. That is why, a professional, whose age is more than 37 years old does not know how the PDS works if he does not studied it additionally. It is must be mentioned that according to the data of the official site WORK.ua about half of the professional patternmakers on the job market are older than 37 , and $59.3 \%$ of them said in their resumes that they were previously employed at the small subsidiary companies, which usually do not use PDS for its high cost. For that reason, the high cost of the PDS is considered as its main disadvantage.
Besides that, although patterns can be drafted directly on the screen, PDS is particularly adept at adapting blocks or modifying patterns stored within the computer. While designing clothes for individual figures usually requires drafting blocks of specific garments. The same goes to the specifics of students' works. Drafting blocks is necessary for beginners, students, who are starting practical pattern cutting as part of fashion degree or diploma courses or for students in upper schools, who are studying advanced dress and textile subjects.

Thus, all of abovementioned categories of users are bound to be stuck in the old-fashioned clothing drafting techniques, which require calculating of blocks parameters by designer himself. However, the low speed of calculation and its inconvenience along with the high risk of occurring mistakes, which have to do with human factor, are major disadvantages, which speak against using such method despite its low cost.

The most common way to calculate the parameters is to use MS Excel or any other spreadsheet that works online or offline. According to information of the service Google Trends, interest in such online tools to design patterns of clothes is constant during the last years (Fig. 1).

However, it is not that convenient way to work because one has to draft a pattern directly on the fashion fabric and to watch at the screen of personal computer simultaneously.

For that reason, the mobile app would be a great mean to speed up the work of clothing designer and make it easy and modern. Besides that, this will be useful for women who make clothes for themselves, in order to create and develop

Comparison of the means of calculation

\begin{tabular}{|l|c|c|c|c|}
\hline \multicolumn{1}{|c|}{ Way of calculation } & Speed & Precision & Cost & Convenience \\
\hline Mobile application & + & + & + & + \\
Pattern design system & & & & \\
(PDS) & + & + & - & - \\
Spreadsheet program & + & + & + & - \\
Electronic calculator & - & - & + & - \\
\hline
\end{tabular}




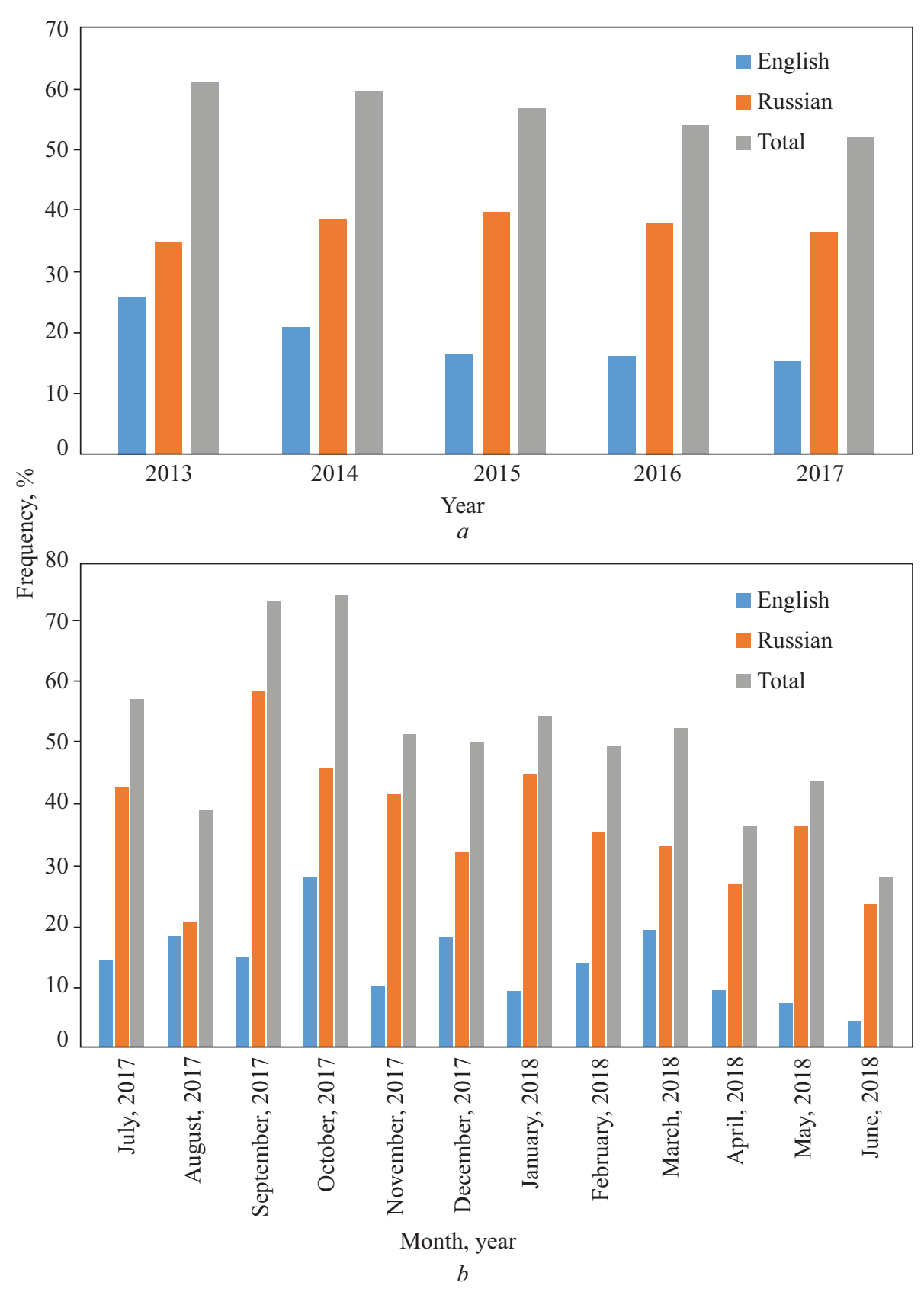

Fig. 1. Analysis of the search queries, which refer to automatization of the garment design, in Google Search

their own individual style, or women who find mass-produced clothes an uneasy fit.

Fashion is an entirely new direction for mobile applications, but it is far from to be exception from the list of possible applications. The opportunities for mobile apps in the fashion domain are very versatile. There are many different mobile apps, which are useful enough to be considered as a great service of modern software in the everyday life of average person. Among them most frequently mentioned are Stylebook [6], Cloth [7], and Polyvore [8]. 


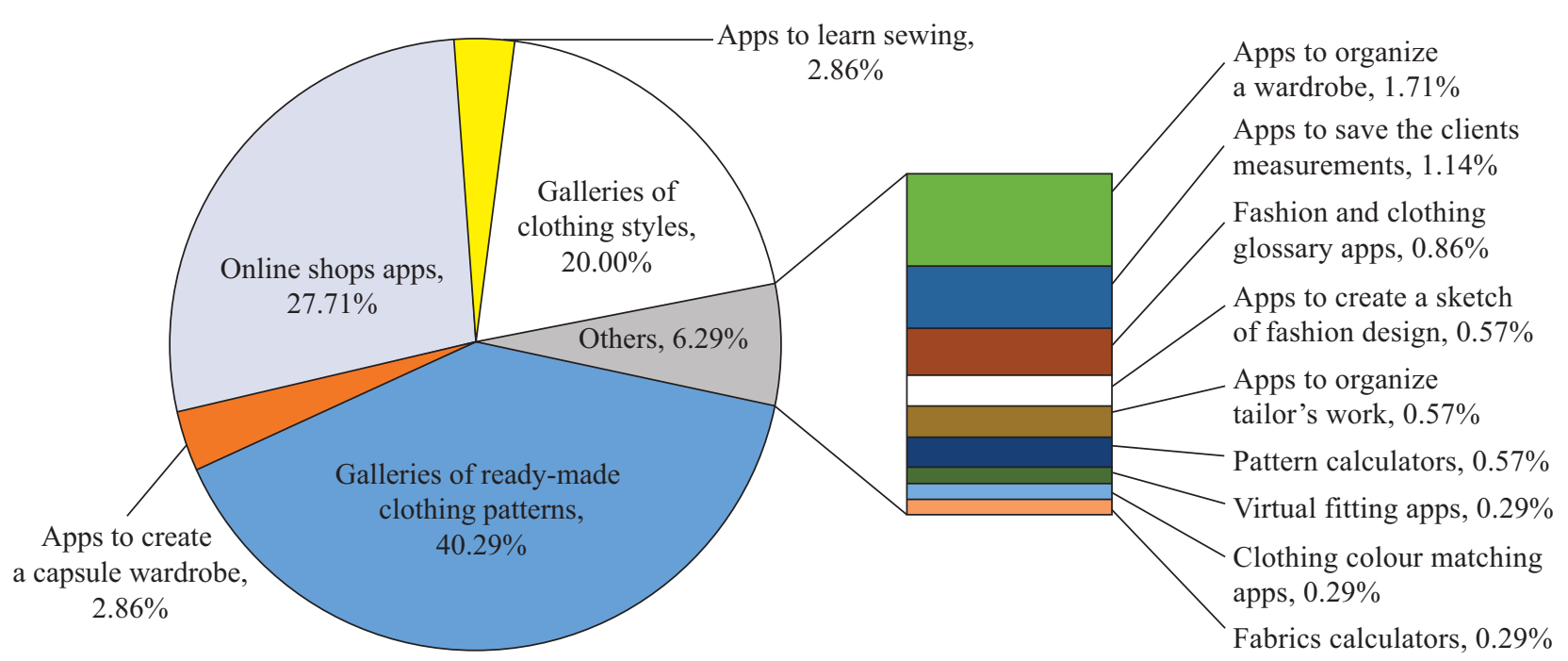

Fig. 2. Types of the mobile applications that are used in garment industry

Stylebook is an expert wardrobe organization and closet management tool created by a fashion industry insider. Cloth is an app for iPhone that makes it easy to save, categorize, and share ones favorite outfits. The app also uses real-time weather data to help user pick his best outfits for current conditions. Few years ago, Polyvore released iOS app, which is surfacing personalized fashion recommendations.

By using Google Play Market, 350 mobile applications, which have something to do with clothing and its design or manufacturing, were discovered. As it shown in the Figure 2, the majority of them are the apps to support fashion distribution market: $27.7 \%$ of them are online shops apps, and $20.0 \%$ are the apps, which represent fashion trends in current season.

Almost a half of the apps might be used in a process of clothing design as these apps content the galleries of clothing patterns. However, the clothing patterns are given for the particular fashion styles and of unrecognizable sizes. For that reason, while they can be used as a guide to construct the garment of the same fashion style the basic pattern, which matches to consumers body measurements, is still needed because it allows one to achieve the required level of accuracy.

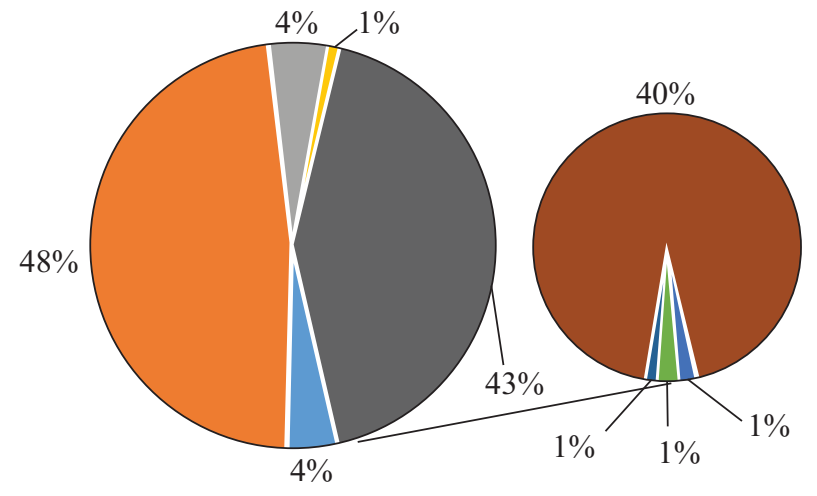

manufacturing $\square$ distribution $\square$ exploitation $\square$ any stage

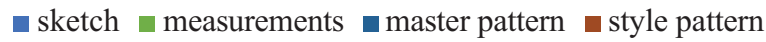

Fig. 3. Categorization of the mobile apps according to the stage of the clothing life cycle they are used at

All of considered mobile apps were categorized according to the stage of the clothing life cycle they refer to (Fig. 3). The stages are as follows: design (consists of creating a sketch, body measuring, designing a basic pattern or master pattern, and designing patterns of the specific fashion style), manufacturing, distribution, and exploitation [9]. As we can see in the figure 3, only two out of four stages are supported by mobile applications. However, the percentage of the mobile apps to calculate any parameters is drastically low. It is only about $1 \%$ of the whole population of the clothing design mobile apps. 


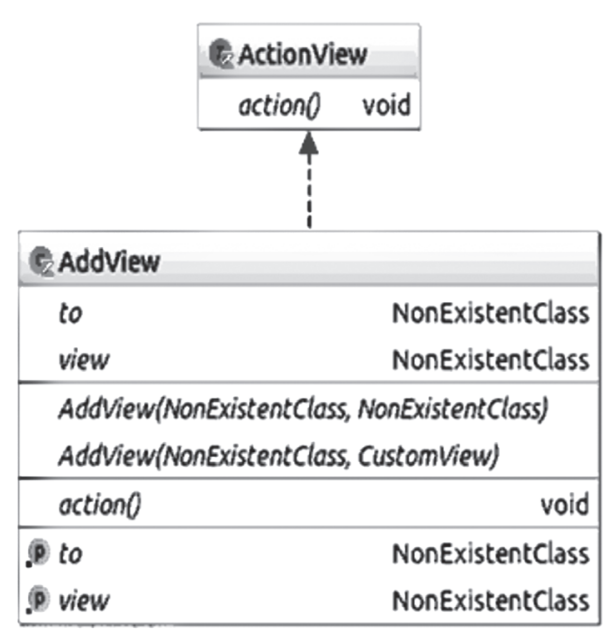

Fig. 4. Analysis of the search queries, which refer to automatization of the garment design, in Google Search

Thus, in the fashion-retailing domain, mobile apps are widely used, but virtually there is no application in apparel design. Which is why the development of the mobile app that will be a means of clothing designer work is a task to be solved.

There are many different pattern-cutting techniques, which are used separately or in complex. Among them, there are some very famous techniques such as Voronin's method [9], Winifred Aldrich [10], Muller \& Son [11], Lubacs [12], Unime $C S$ and others. To create a mobile app, it is proper to use a technique that might be applied to the wide range of menswear, womenswear or children's wear. Besides that, the technique must belong to calculation methods. It is mandatory requirement due to necessity to have some specific equipment for the realization of other methods. For that reason, Voronin's unique method of tailoring menswear without fittings is considered as improper for the further development of the mobile app.

Lubacs and UnimeCS methods compose a subgroup of client-oriented methods of patternmaking. Such methods give promising results for the experienced user. However, there are no many designers, who use these methods due to the high cost of education. Another reason is complexity of the methods. Most of users choose simple methods that are based on the few body measurements rather than complex methods, which require special training.

The main task of the work is to develop a mobile application for calculating the parameters of the main templates. The choice of a method of forming templates, which is the method of calculation for application to a wide range of clothing, and is not complex according to the instructions for drawing up a pattern of a clothing block [8].

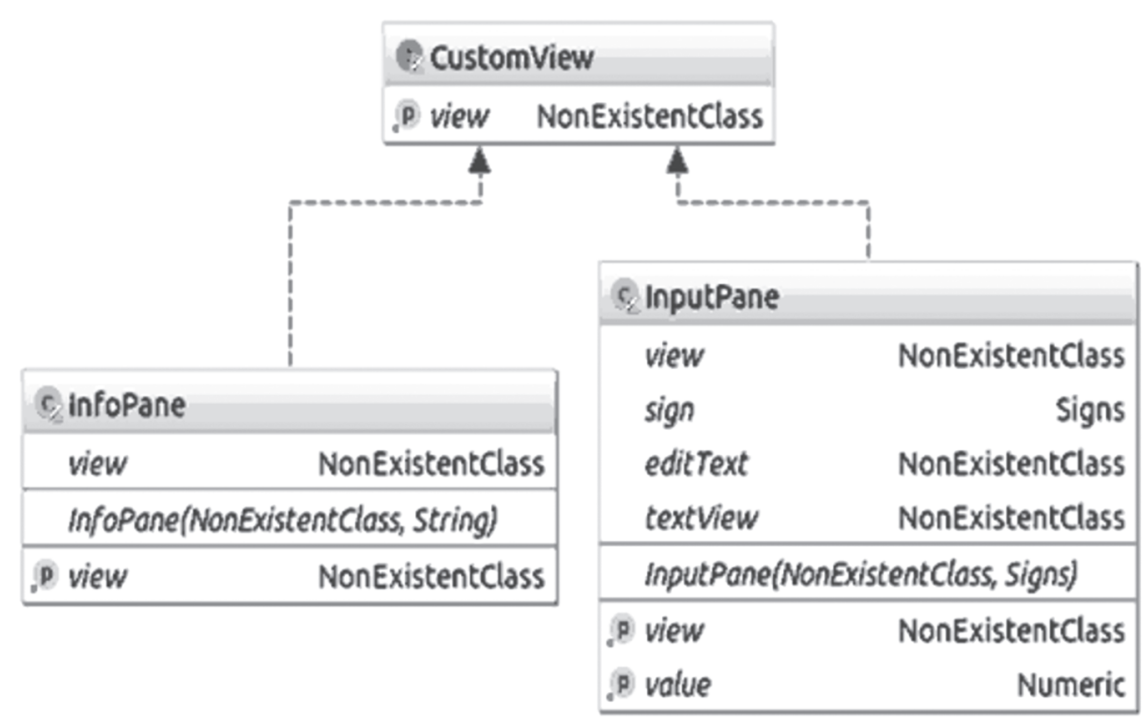

Fig. 5. Own graphic object class diagram 
For accurate and automated computing, you need to use the necessary software. It is convenient to use MS Excel for difficult calculations. However, this is hard to do on mobile devices because MS Excel is not designed for mobile devices, so its use on phones is not rational. That is why the app for mobile devices on the Android operating system was developed. The Android operating system is the most popular mobile operating system. Android is based on a modified Linux kernel and other open source software designed for touch screen mobile devices such as smartphones and tablets. The operating system is developed and maintained by Google. $75 \%$ of mobile devices run on the Android operating system. There are many ways you can create applications for the Android operating system. To write applications to the Android operating system, many programming languages (Java, C \#, Kotlin, C++, Python) and integrated development environments (IDE) (Android Studio, IntelliJ IDEA, Visual Studio with Xamarin, Pycharm with Kivy) are used. We created a mobile app for using

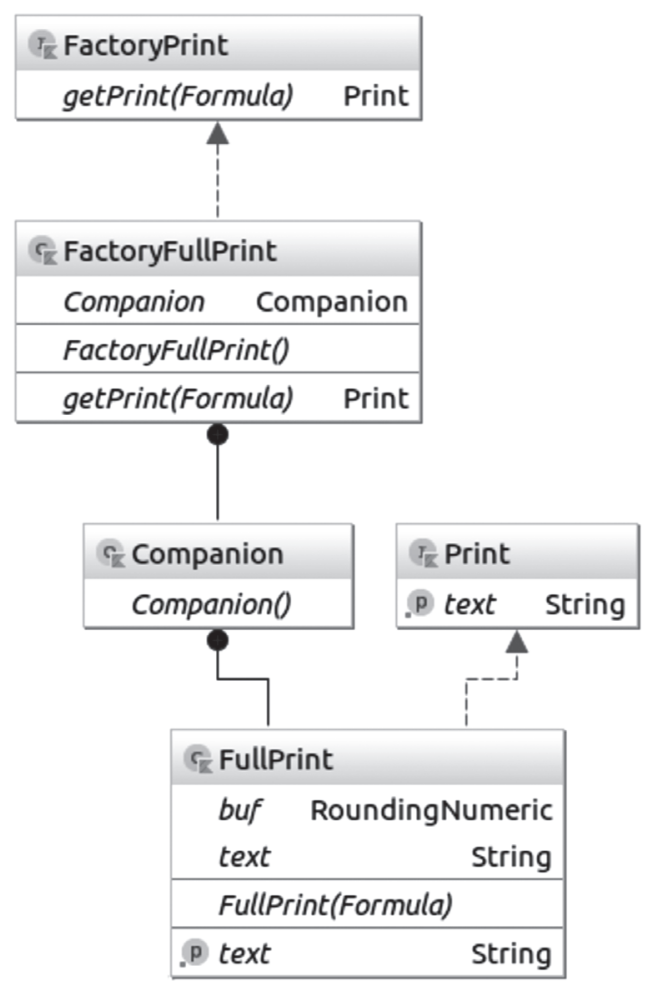

Fig. 6. Class diagram of the formula visualization module

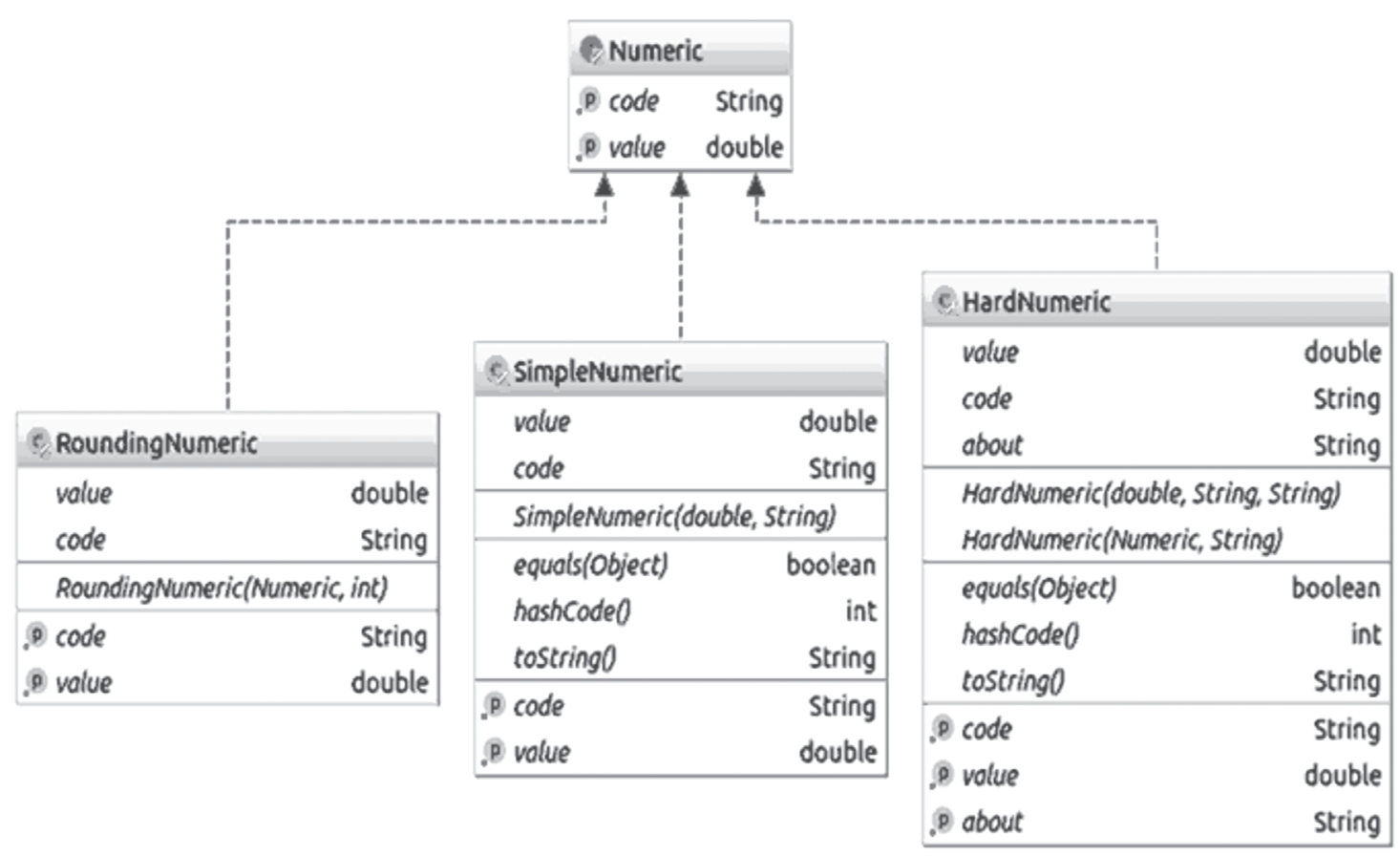

Fig. 7. A class diagram that describes the data structures used for calculating and visualizing formulas 


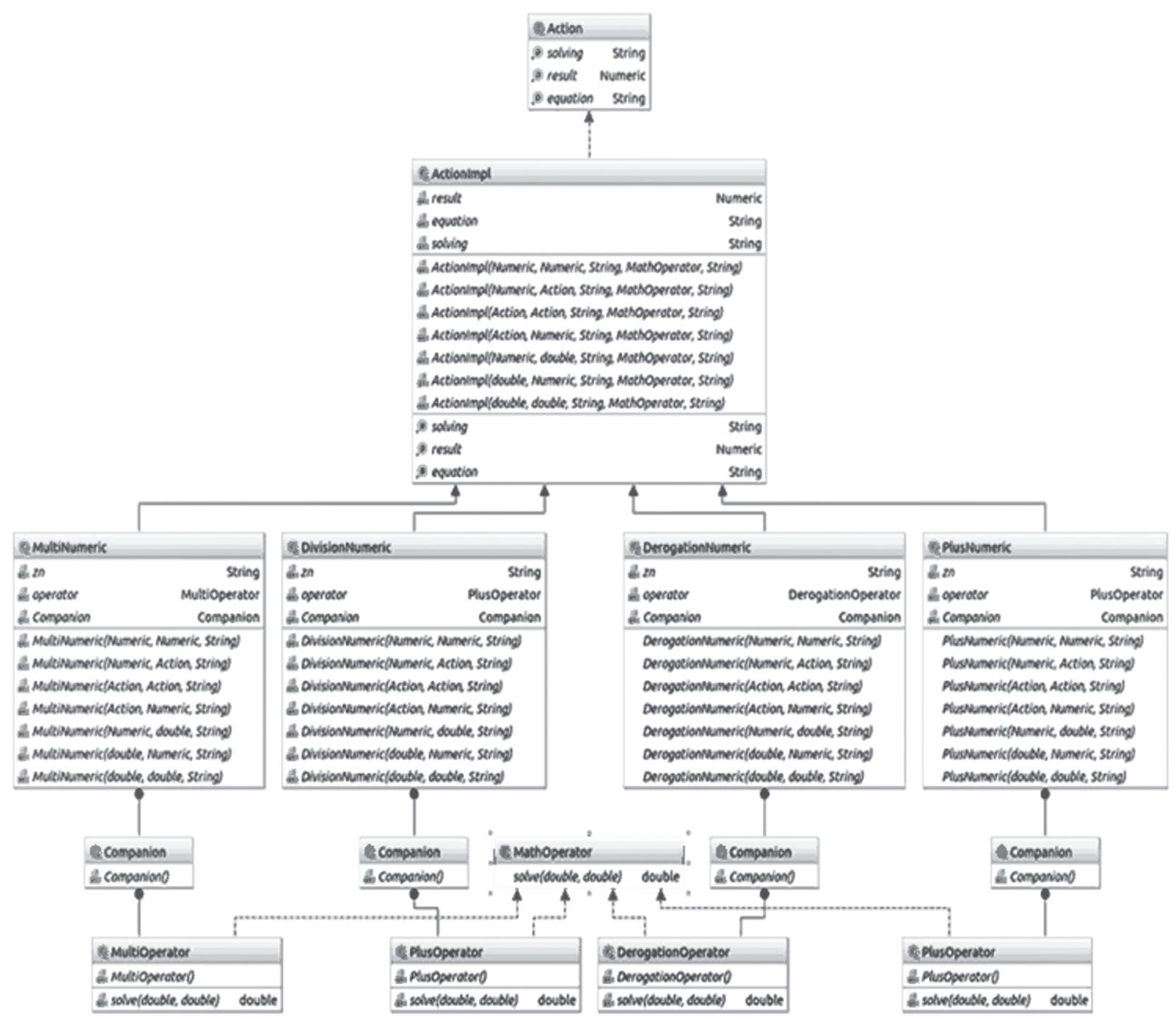

Fig. 8. A class diagram that represents the module that contains the logic of calculations

the Android integrated platform - Android Studio. This program is freeware, distributed under the Apache 2.0 license, official support provided by Google. Android Studio is based on IntelliJ IDEA Community Edition, which is supported by Jet Brains. Applications for the Android operating system can be created in many programming languages. Java is now the most popular language for Android development. However, for the creation of our application, we used a more modern and convenient programming language Kotlin [13-15].
Important advantages of Android Studio: are collection of typical interface elements and a visual editor for their layout, which provides a convenient preview of the future application, code light, analysis and error detection, integration with the Git version control system. Android Studio has a handy developer console, hints for optimization, Google Analytics metrics. To build such an application, the griddle assembly system is used.

The choice of the Kotlin programming language is due to the fact that it is more modern 
and easier to write programs. Kotlin can compile in three variations: bytecode JVM, JavaScript, Native. You can also use all Java-frames and libraries. Kotlin can be converted to Java and vice versa. This programming language is null-safe. It supports properties that do not support Java. This allows you to make the code presentable and do not waste time creating the getters and setters. Kotlin uses more modern lambda than Java. Kotlin implemented a simpler design procedure. Another important feature is the "String template", which allows you to format the strings quickly and easily.

To create the kernel of the application, we used an object-oriented programming paradigm. All the main logic of the program is described separately using the classes of individual packages. A class is a template that has certain fields and methods. This approach allows you to apply different shells to one common kernel of the application.

Main Activity is a class that describes the work of the user with the program (buttons, text panels, fields for inputting data). The view package contains classes for easy work with visual objects in the program. The core of the core is the core logic of the program. It contains classes and interfaces for mathematical calculations and a description of all mathematical notation.

There are two smaller packages in the view package: struct and action. The struct contains classes that describe the work of graphic objects, and in action, there are classes to work on these objects (Fig. 4).

Action View interface that describes what to do. Add View completes the addition of the view element (Fig. 5).

The Custom View interface describes which graphic element it returns. Info Pane is a text panel with information. Input Pane is a panel for entering values from a formula; it also returns this value with its conditional notation. The core package contains classes and interfaces for mathematical calculations and description of all mathematical notation. Here is stored all the main logic of the program.

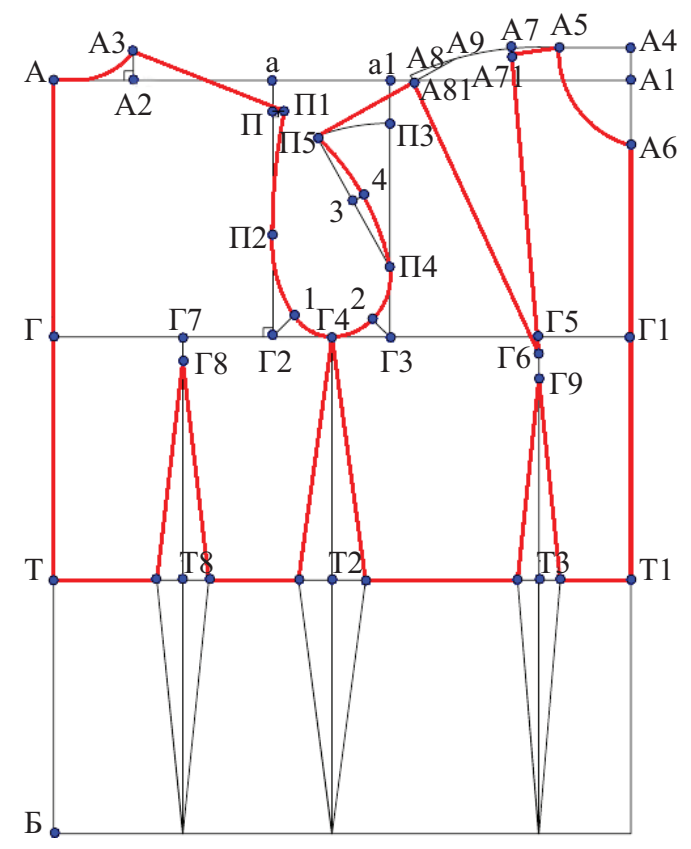

Fig. 9. Image of the final draft of the clothing block pattern

Signs - this is an enum-class (enumeration), mathematical notation and description are stored here. In a simple form of transfer is a list of named constants.

But Kotlin's transfer has a more complex functionality than in other programming languages. They can interpret constructors, methods, and instance variables. The formulas package contains all formulas and some functionality over them. The num package describes the classes with numbers and the main function that can be performed over them. In the Print package [14], there are classes for textual derivation of formulas.

The Print interface contains one field that describes the text representation of the formula. In order for the code to always have the same output, the design pattern of the factory method is implemented. Factory interface. It is implemented by the Factory Full Print class. Within this class, a Full Print class is created that implements the Print interface. And the get Print method returns a specific Print implementation. The code hides a specific implementation, and it becomes more abstract (Fig. 6). 
The Formula Interface describes what formulas are composed of. The formulas contain symbols and descriptions of the actions they perform. The implementation package implements this interface.

The num package contains the following packages (Fig. 7).

Action contains actions on numbers (Fig. 8).

This application architecture allows you to quickly create a flexible application on Android. We can add any new module that will expand the application. Some of the basic design patterns used factory method and decorator. This allows us to hide the implementation of interfaces and wrap some objects in others, this allows us to expand their functionality. The architecture of the application meets modern standards.

Our mobile application can be seen if you follow the link https://www.dropbox.com/s/diioq3rot5kya1h/Master\%20Pattern.apk?dl=0. To start working with the application you need to enter the correct data, after which you need to click on the "Next" button. After clicking the "Next" button, the check is performed to fill all fields. If the fields are not filled, a warning will appear and they will be filled with zeros. After filling in all the fields, the program calculates the result and passes to the calculation of the next indicator.

The mathematical model of calculations has a trivial form

$$
L=T+P+a,
$$

where $L$ is length of the construction line, $\mathrm{cm}$; $T$ is measurements of the body, $\mathrm{cm} ; P$ is amount of eases, $\mathrm{cm}$; $a$ is constant. Interim calculations of the construction describe at each new step of the mobile application.

The calculation is given for the specific instruction of the clothing block pattern drafting, which is described in [16]. The user is provided with image of the final draft that will be obtained if the app is applied in a proper way (Fig. 9).

Similar mobile application might be developed for any instructions to draft clothing pattern blocks. Thus, required premises to apply mobile devices in apparel design are developed.

For the first time, a mobile application was developed for the urgent and rapid calculation of parameters to design basic blocks of the clothing patterns. The patterns might be constructed directly on the fashion fabric by using the developed mobile app as a calculator and notepad. The precision of the calculation is the same as of other calculation methods while the risk of accidental mistakes due to the human factor is excluded from the designing process.

Clothing designers can use it as well as students for training in their study of clothing design. It is useful tool for the people, who make their living on garment design for individual customers or like to sew for themselves. The calculation of parameters is determined quickly and without economic costs.

Thus, the main objective of the study was achieved through developing the mobile application to calculate the parameters of clothing basic blocks, and by doing so the support of weakly automated clothing design process in tailor shops and other small clothing design enterprises was ensured.

\section{REFERENCES}

1. Zakharkevich, O. V., Kuleshova, S. G. (2017). Development of the method of scaling patterns and virtual garments forms. Vlakna a Textil., 4, 34-40.

2. Gnidenko, S. G., Yudin, L. P., Kuzmichev, V. E. (2007). Arkhitectura ekspertnoi systemy otsinky yakosti dyzainu odiahu of expert system of quality assessment of clothes' designs. Sewing Industry, 5, 52-54.

3. Selezneva, A. V., Slavinskaya, A. L. (2014). Designing effect of woman's figure, created corset, consider psikhofiziologic comfort, Proceedings of higher education institutions. Textile industry Technology, 2(350), 102-106.

4. Yakymchuk, D., Yakymchuk, O., Orlenko, O. (2017). Study of cutting presses in designing a women's costume for hospitality industry. Eastern European Journal of Enterprise Technologies, 5, 1(89), 26-36. 
5. Zakharkevich, O., Zhylenko, T., Shvets, G. (2018). Expert system to select the fabrics for transformable garments. Vlakna a Textil., 2, 105-112.

6. Stylebook on the App Store. URL: https://itunes.apple.com/us/app/stylebook/id335709058?mt=8 (Last accessed: 21.08.2018).

7. Cloth. URL: http://www.clothapp.com/(Last accessed: 21.08.2018).

8. Polyvore (iOS) - Product Hunt. URL: https://www.producthunt.com/posts/polyvore-ios (Last accessed: 21.08.2018).

9. Aldrich, W. (2008). Metric pattern cutting for women's wear. Wiley-Blackwell.

10. Characteristics of the design method M. Myuller \&Son. URL: http://wellconstruction.ru/konstr2/harakteristikametodiki-konstruirovaniya-m-myuller-i-syin (Last accessed: 21.08.2018).

11. Krasnikova-Aksenova, L. Ya. (1995). Uchebnik po modelirovanyiu odezhdy po metodu Lubaka. Moscow [in Russian].

12. Slavinska, A. L. (2007). Osnovy modulnogo dyzainu odiahu. Khmelnitsky [in Ukrainian].

13. StartAndroid. URL: http://startofandroid.com/ (Last accessed: 21.08.2018).

14. Gerbert Shildt. (2015). Java 8. Polnoe rukovodstvo. Moscow [in Russian].

15. Kotlin Programming Language. URL: https://kotlinlang.org/ (Last accessed: 21.08.2018).

16. Meshkova, E. V. (2006). Dizain odiezhdy. Uchiebnoe posobie. Moscow.

Received 29.08.18

\author{
T.I. Жиленко ${ }^{1}$, А.М. Кудрявщев ${ }^{1}$, О.В. Захаркевич ${ }^{2}$ \\ ${ }^{1}$ Кафедра математичного аналізу та методів оптимізації \\ Сумського державного університету, \\ вул. Римського-Корсакова, 2, Суми, 40007, Україна, \\ +380 66188 6616, t.zhylenko@phe.sumdu.edu.ua \\ ${ }^{2}$ Кафедра технології та конструювання швейних виробів \\ Хмельницького національного університету, \\ вул. Інститутська, 11, Хмельницький, 29016, Україна, \\ +38067 749 1647, zbir_vukladach@ukr.net

\section{МОБІЛЬНИЙ ДОДАТОК ДЛЯ ОБЧИСЛЕННЯ ПАРАМЕТРІВ БАЗОВОЇ КОНСТРУКЦІї ПЛЕЧОВОГО ОДЯГУ}

Вступ. На сьогодні швейна промисловість стрімко перетворюється на високотехнологічну, капіталомістку індустрію завдяки сучасним досягненням технології, що сприяє високій якості проектування, розкрою та виготовлення одягу. Розвиток цієї галузі у виробничому секторі $є$ досить інтенсивним, тому надзвичайно важливим є забезпечення відповідних фахівців та дослідників сучасними технологічними розробками для створення конкурентоздатної продукції. Одним із засобів, що дозволяють залучити нових споживачів продукції, які орієнтовані на технології та живуть в режимі он-лайн, є мобільний сервіс (мобільні додатки) Stylebook, Cloth, Polyvore та інші. Проте зазначені програми містять переважно галереї моделей одягу або конструкції для певних моделей одягу, які зазвичай не мають чітко вказаних розмірів.

Постановка проблеми. Мобільні додатки, які сьогодні доступні для використання у швейній галузі, зорієнтовано на збут уже готової продукції. В той час, як етапи проектування та виготовлення забезпечені програмними продуктами лише на «домашньому» рівні, існує потреба в розробці мобільних додатків, що будуть спрямовані на використання саме фахівцями швейної галузі. Для розробки зазначеного додатку доцільно обирати методику конструювання, яка є водночас простою, доступною і відомою для широкого кола користувачів.

Мета. Розробка мобільного додатку для розрахунку параметрів основних деталей плечового одягу.

Матеріали й методи. Розробку програми виконано у операційній системі Android з використанням сучасної та зручної мови програмування Котлін.

Результати. Шляхом порівняльного аналізу засобів розрахунку базових конструкцій одягу доведено доцільність використання мобільних додатків у швейному виробництві. Розроблено класифікацію наявних мобільних додатків, що використовуються або можуть бути використані у процесах конструювання та виготовлення одягу. Кількісний аналіз класифікації підтвердив вихідну гіпотезу щодо відсутності мобільних додатків, які використовуються на етапі побудови типової базової конструкції. Для розрахунку параметрів базової конструкції плечового одягу було розроблено програму мобільного додатку, який забезпечує підтримку автоматизованого процесу створення конструкцій одягу як в умовах індивідуального чи дрібносерійного виробництва, так і в процесі навчання. 
Висновки. Використання розробленого пакету дає змогу виконати конкретне креслення для будь-якого розміру плечового виробу. Користувач отримує координати базової конструкції моделі, що готова до розробки лекал у масовому виробництві або при індивідуальному розкрої.

Ключові слова: мобільний додаток, Kotlin, клас, пакет, інтерфейс.

\author{
Т.И. Жиленко ${ }^{1}$, А.М. Кудрявщев ${ }^{1}$ О.В. Захаркевич \\ ${ }^{1}$ Кафедра математического анализа и методов оптимизации \\ Сумского государственного университета, \\ ул. Рымского-Корсакова, 2, Сумы, 40007, Украина, \\ +380661886616, t.zhylenko@phe.sumdu.edu.ua \\ ${ }^{2}$ Кафедра дизайна одежды и технологий \\ Хмельницкого национального университета, \\ ул. Институтская, 11, Хмельницкий, 29016, Украина, \\ +380 67749 1647, zbir_vukladach@ukr.net

\section{МОБИЛЬНОЕ ПРИЛОЖЕНИЕ ДЛЯ РАСЧЕТА ПАРАМЕТРОВ БАЗОВОЙ КОНСТРУКЦИИ ПЛЕЧЕВОЙ ОДЕЖДЫ}

Введение. Швейная промышленность быстро превращается в высокотехнологичную, капиталоемкую индустрию благодаря быстрым достижениям технологии, способствующей высокому качеству проектирования, раскроя и изготовления. Отрасль является одной из наиболее быстро развивающихся в производственном секторе, и поэтому чрезвычайно важно обеспечить возможность специалистам отрасли и исследователям идти в ногу с изменениями для достижения желаемой конкурентоспособности продукции. Одним из средств, позволяющих обеспечить привлечение новых потребителей продукции, которые ориентированы на технологии и живут в режиме он-лайн, - это мобильный сервис (мобильные приложения): Stylebook, Cloth, Polyvore и другие. Указанные программы преимущественно содержат галереи моделей одежды, или конструкции для определенных моделей одежды, которые обычно не имеют четко указанных размеров.

Постановка задачи. Мобильные приложения, которые сегодня доступны для использования в швейной отрасли, ориентированы на сбыт уже готовой продукции. В то время, как этапы проектирования и изготовления обеспечены программными продуктами только на «домашнем» уровне, существует потребность в разработке мобильных приложений, которые будут направлены на использование именно специалистами швейной отрасли. Для разработки приложения целесообразно выбрать методику конструирования, которая является простой, доступной и известной для широкого круга пользователей.

Цель. Разработка мобильного приложения для расчета параметров основных деталей плечевых изделий.

Материалы и методы. Разработка мобильного приложения выполнена в операционной системе Android с использованием современного и удобного языка программирования Котлин.

Результаты. Путем сравнительного анализа средств расчета базовых конструкций одежды доказана целесообразность использования мобильных приложений в швейном производстве. Разработана классификация существующих мобильных приложений, которые используются или могут быть использованы в процессах конструирования и изготовления одежды. Количественный анализ классификации подтвердил исходную гипотезу об отсутствии мобильных приложений, используемых на этапе построения типовой базовой конструкции. Для расчета параметров базовой конструкции плечевой одежды была разработана программа для мобильного приложения, которое обеспечивает поддержку автоматизированного процесса создания конструкций одежды как в условиях индивидуального или мелкосерийного производства, так и в процессе обучения.

Выводы. С помощью разработанного пакета можно выполнить конкретный чертеж для любого размера плечевого изделия. Пользователь получает координаты базовой конструкции модели, которая готова к разработке лекал в массовом производстве или в индивидуальном раскрое.

Ключевые слова: мобильное приложение, Kotlin, класс, пакет, интерфейс. 